\author{
Г. А. Мольков \\ Институт лингвистических исследований РАН \\ (Россия, Санкт-Петербург) \\ georgiymolkov@gmail.com
}

\title{
ОРФОГРАФИЧЕСКИЕ ПРИНЦИПЫ КИПРИАНОВСКОГО КРУЖКА (НА МАТЕРИАЛЕ РУКОПИСИ ГИМ СИН. 675)*
}

\begin{abstract}
Статья посвящена описанию орфографических принципов, лежащих в основе системы написаний старшего списка славяно-русского перевода Евхология Великой церкви, выполненного по заказу митрополита Киприана русскими книжниками. В орфографии рукописи представлено значительное количество черт, обусловленных влиянием болгарской письменной традиции. Отбор этих черт произведен по единому принципу и формирует специфическую для периода рубежа XIV-XV вв. орфографическую систему в тексте, не имевшем среднеболгарского протографа. Возможно, разработка подобной орфографической системы принадлежит непосредственно Киприану и была задумана специально для новых производившихся на Руси переводов.
\end{abstract}

Ключевые слова: второе южнославянское влияние; переводы митрополита Киприана; Евхологий Великой церкви; орфографическая норма

Славянский перевод Евхология Великой церкви представлен двумя пергаменными кодексами, датирующимися рубежом XIV-XV вв., из Синодального собрания ГИМ - Син. 675 и Син. 900. Написанные с разницей в 15-20 лет (Син. $675-$

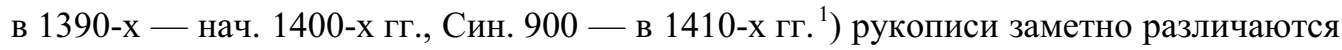
по графико-орфографическим установкам писцов. Список Син. 900 не имеет в орфографии новых черт, его письмо традиционно для древнерусских рукописей XIV в. Правописание списка Син. 675 в Описании рукописей Синодального собрания характеризуется как «русское с примесью сербского» [Горский, Невоструев 1869: 149]. Изучение языка перевода Евхология Великой церкви, проведенное Т. И. Афанась-

\footnotetext{
* Исследование осуществлено при поддержке гранта РГНФ № 14-04-00150а.

${ }^{1}$ Такая датировка предлагается А. А. Туриловым, см. [Афанасьева 2015: 38].
} 
евой [Афанасьева 2014: 239], показало, что на самом деле список имеет русское происхождение, а «сербские» черты письма рукописи должны быть интерпретированы как отражение южнославянского влияния (далее - 2-е ЮСлВ) на русскую письменность, проявляющегося в орфографии с конца XIV в.

Перевод Евхология содержит ряд ярких языковых черт, связывающих его с нормами переводческих кружков Евфимия Тырновского и митрополита Киприана [Там же: 239-243], что позволяет предположить, что перевод могли осуществить книжники круга митрополита Киприана. В связи с этим орфография списка Син. 675 заслуживает особого внимания. Присутствие в его письме южнославянских орфограмм непосредственно связано с южнославянскими по происхождению нормами, в соответствии с которыми переводился этот текст. Согласно наблюдениям М. Г. Гальченко, «наиболее рано и интенсивно признаки 2-го ЮСлВ проявляются в тех рукописях, которые содержали неизвестные ранее на Руси тексты или редакции текстов» [Гальченко 2001: 125]. Однако список перевода Евхология Великой церкви несколько выделяется на фоне рукописей, исследованых М. Г. Гальченко. В ряде статей исследовательницы, вошедших в собрание её трудов [Гальченко 2001], описываются основные графико-орфографические черты древнерусских списков новых южнославянских переводов, в то время как перевод Евхология был осуществлён, вероятнее всего, древнерусскими книжниками [Афанасьева 2014: 247]. Таким образом, черты 2-го ЮСлВ в Син. 675 - результат сознательной кодификаторской деятельности восточнославянских книжников, не связанной со среднеболгарским антиграфом текста. Наличие традиционного по правописанию списка Син. 900 только подчёркивает тот факт, что в Син. 675 представлена попытка предложить образец новой орфографии, обслуживающий новые, выполненные в кружке Киприана переводы. Набор графико-орфографических особенностей и соотносительный объём их использования на письме в Син. 675 в совокупности не находит полных аналогий среди рукописей данного периода, описанных на сегодняшний день. Представленное ниже описание этой системы показывает, что в ней наряду с удачными решениями были и слабые места, которые обусловили её невостребованность в последующей традиции.

\section{1. Писцы Син. 675}

Рукопись Син. 675 выполнена на пергамене, содержит 217 листов. Кроме основного уставного почерка, в разных частях в ней есть вставки восьми других почерков: 1) л. 1-7 об., строки 1-6 (оглавление к ЕВЦ написано уставом, заметно отличающимся от основного одинаковыми по толщине горизонтальными и вертикальными штрихами; наиболее ярко см. начертание w); 2) л. 7 об., строки 7-15 (почерк наклонный, переходящий к полууставному); 3) л. 63-63 об., л. 72 (7-18 строки) 72 об., заголовки на л. 66 об., 69 об. (устав - более вытянутый, чем основной, горизонтальные мачты букв чуть загибаются вправо в верхней части; используется только 
монограф \ после согласных); 4) л. 143 (полуустав); 5) л. 143 об.-151 об. (полуустав, отличный от почерка на л. 143 - с более сильным наклоном, иные начертания букв ж, ‘ и др.); 6) л. 158-158 об. (устав более мелкий, чем основной, линии букв тоньше); 7) л. 164-165 об. (устав - более светлыми чернилами, отличный от основного и от почерка на л. 158-158 об.; в частности, в составе диграфа $\boldsymbol{w}$ используется $\boldsymbol{w}$ с высокой серединой); 8) л. 178 об. (6-18 строки) - 179 (1-6 строки), л. 198 об. - 199, л. 210 (с 12-й строки) - 210 об. (устав, очень похожий на основной, но отличающийся на графическом уровне исключительным употреблением монографа ү и написанием ы только с ъ в левой части; из диакритики используется только паерок).

Черты южнославянского влияния присутствуют в системах всех перечисленных почерков Син. 675, однако в наиболее полном виде и в большом по объему тексте они представлены в основном почерке рукописи. Его подробное рассмотрение позволяет описать системные взаимоотношения различных орфограмм, выработку которых можно связывать с кодификаторской деятельностью митрополита Киприана и книжников его круга.

\section{2. Графико-орфографические особенности основного почерка Син. 675}

\section{1. Инновации в употреблении отдельных графем}

В написании и употреблении ряда графем в Син. 675 представлены некоторые черты, инновационные по отношению к древнерусскому письму XIV в.

Привлекает внимание набор графем, применяемых для обозначения звука [u]. Во-первых, писец последовательно использует диграф or (вместо обычного в XIV в. ү) независимо от позиции в слове и строке. Этот вариант является основным в почерке для передачи [u]. Традиционный монограф ฯ употребляется в редких случаях и, повидимому, при необходимости уместить текст в строку. Так, на л. 16, стр. 1 читается:

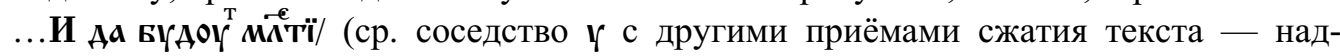
строчным т, при обычном для почерка написании глагольных -ть в строке, и ї в конце); также, например, вариант ү периодически появляется в завершающей фор-

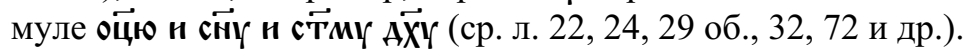

Наряду с диграфом не только на конце строки (хотя достаточно редко) встречается и графема 8. Как отмечает М. Г. Гальченко, «с рубежа XIV и XV вв., очевидно, и не без влияния южнославянских графико-орфографических норм в восточнославянской письменности начинает восстанавливаться употребление диграфа or и заменяющей его лигатуры 8 после букв согласных» [Гальченко 2001: 246]. Можно добавить, что в ряде случаев влияние южнославянских почерков также сказывается в написании овала 8 отдельно от верхней части: л. 9 об., стр. 2, 3; л. 11, стр. 13; л. 29 об., стр. 2 ; л. 30 об., стр. 5 ; л. 42 об., стр. 18; л. 45 , стр. 15 и др. ${ }^{2}$

\footnotetext{
${ }^{2}$ Ср. замечание М. Г. Гальченко [Там же: 217] об аналогичном явлении в Каноннике 1408 г.
} 
Употребление основным писцом Син. 675 графемы ы (с ь в левой части) также может быть связано с южнославянским влиянием ${ }^{3}$. Написание ы используется в почерке в качестве основного на протяжении всей рукописи одновременно с менее частым традиционным для древнерусской графики древнейшего периода ы. Употребление того или иного варианта, видимо, ничем не обусловлено: равъ тєв' и равын' 17 и т. п. Вариант ы появляется на отдельных листах по 1-2 раза. В отличие от основного почерка исключительно ы используется в 1-м дополнительном почерке, и исключительно ы - в почерке 8-м.

\section{2. Набор южнославянских признаков}

В настоящем разделе мы рассмотим ряд особенностей письма Син. 675 с опорой на классификацию, предложенную М. Г. Гальченко на основе данных 83 рукописей. Южнославянские признаки исследовательница группирует в рамках минимального, расширенного минимального и максимального их набора в почерке [Гальченко 2001: 291-293]. Такое рассмотрение позволит показать специфику изучаемого кодекса на фоне уже описанных данных.

\subsection{1. Минимальный набор}

В основном почерке Син. 675 представлены все признаки из минимального набора, к которым М. Г. Гальченко относит: 1) использование запятой; 2) употребление акцентных знаков (хотя бы одного, чаще всего кендемы); 3) использование паерка; 4) употребление а в соответствии с [ja]; 5) использование ї-десятеричного перед буквами гласных; 6) наличие написаний с жА (ж) в соответствии с *dj [Гальченко 2001: 291].

В дополнение к признакам минимального набора в настоящем разделе будут рассмотрены орфограммы Син. 675, связанные с влиянием болгарской письменности, которые М. Г. Гальченко в своих описаниях не рассматривает.

Практически все признаки минимального набора в Син. 675 употребляются последовательно, на протяжении всей рукописи. Специфической особенностью почерка является то, что для признаков, связанных с дистрибуцией графем, в Син. 675 есть примеры гиперкорректизмов на их основе. Рассмотрим перечисленные признаки, дополнив их описанием показательных орфограмм, не включённых в схему М. Г. Гальченко (условно отнесём их также к минимальному набору).

\subsubsection{1. Использование пунктуационных знаков}

Наряду с традиционной точкой в Син. 675 активно используется запятая. По свидетельству А. А. Турилова, «самым ранним примером употребления запятой в дати-

${ }^{3} \mathrm{Cp}$. учет данного параметра как «характеризующего проявление 2-го ЮСлВ в древнерусских рукописях» в «Сводной таблице графико-орфографических признаков 2-го ЮСлВ в древнерусских рукописях конца XIV-XV в.», составленной М. Г. Гальченко [Гальченко 2001: 384]. 
рованной рукописи, написанной на Руси восточнославянским уставом конца XIV в., является Онежская Псалтирь 1395 г. (ГИМ, Муз. 4040), созданная скорее всего в Москве» [Турилов 2012: 542]. В переписанных в Константинополе рукописях этот знак появляется уже в 80-х гг. [Гальченко 2001: 247].

На отдельных листах рукописи запятая может появляться чаще точки, напр.:

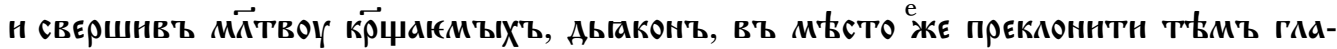

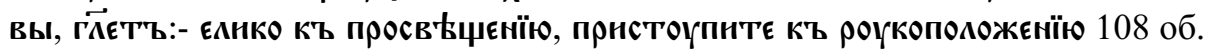

Для Син. 675 характерно использование точек двух видов: обычных чёрных и больших по размеру красных (ср. [Осипов 2010: 124]). Использование большой красной точки в рукописи очень активно. Например, в чине «о єжє како достонтъ

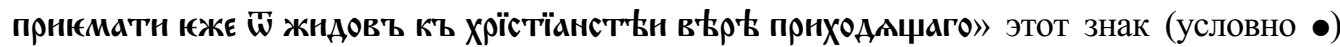
используется для разделения однородных членов: н'Ккоюю ноужєю и нънєволєнӥюмъ

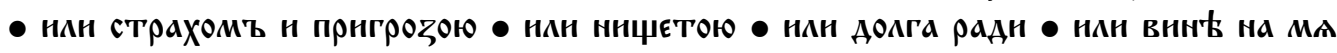
ПодвнЖацї̈А • нан ... 194.

Таким же разнообразием отличается в рукописи и пунктуационное оформление конца синтагмы (перед киноварной буквой) и абзаца. Чаще всего для этого используется двоеточие (в конце абзаца - наряду с :- или $\because$ ), но может быть использована также точка с запятой.

\subsubsection{2. Употребление надстрочных знаков}

В Син. 675 употребляется полный набор диакритических знаков, внесённых в русскую письменность со 2-м ЮСлВ. Новая диакритика заметно реже употребляется на первых 40 листах рукописи, но в дальнейшем она присутствует на каждом листе, её употребление постепенно учащается к концу кодекса. Наибольшей активностью (в рукописи в целом) отличаются оксия и вария.

Оксия используется уже на первых 40 листах, хотя только в части случаев пере-

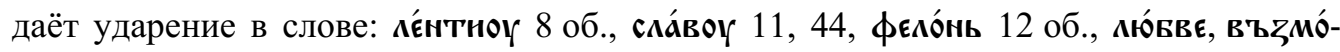

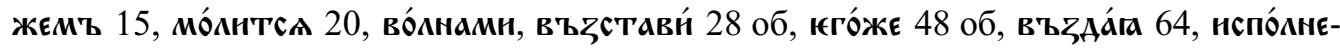
наa 171 об., Хо́тАщаa 179 и др. Также она используется не как знак ударения, а в позиции, обычной для знака придыхания (см. 2.2.1.3) - над второй из двух букв, пе-

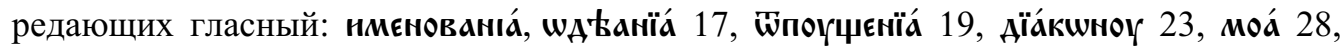

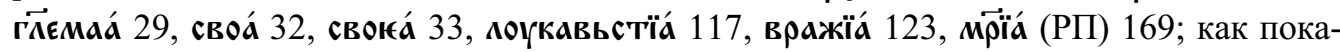
зывают примеры, в этой функции оксия применяется только над $\mathbf{a}$, передающей [ja]. Во второй половине рукописи встречается постановка оксии над односложными словами: сь́́н 118, ви́ 185 (и, видимо, также въzвєсекнтььс́ 51 об.). Встретился также пример оксии над начальной гласной: а́щє 32; а также над согласной (вместо т, ь ?): ӧѓнь 65, тождеовради́а 66 об., Шиверѓшн мн са 67, къ въсто́кшмъ 179 об. (ср. также неясные примеры с двумя оксиями в слове: ра́нско́мог 211 об.; или с оксией на ко-

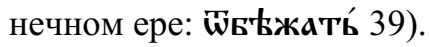


Кендема ${ }^{4}$ ставится над односложными словами ${ }^{5}$ : ӧ (предлог) 17 об., 61 об. (bis), тӓ 33, тӧ 39 об., 211, 213 об., съй (“сей”) 43, 50 об. (о стй см. также 2.2.2.2), сьїн 58,

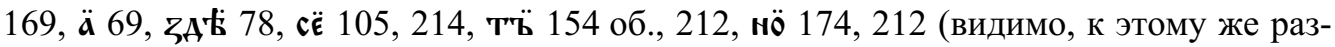
ряду можно отнести и пример молнмсї 33); также встречается над второй из двух букв, передающих гласный: въдсымаём́ 26 об., завлоүждьшєё 27, твоёю 33 об., твоёга 56 об., аврайма 57 об., свершакмыг̈ 67, жнтнӓ 112 об., єй 154 об., прїАєжныӓ 191 и др.; в том числе над начальной гласной слова, например: ӧсвовожага 34, ӧжнвотворн 42 об., ёжє 62, ӓп्Т хьскоүю 104 об., ёсн 190.

Исо чаще всего используется над формами местоимения $\mathbf{n ( ж \varepsilon ) ~ ( и с п о л ь з о в а н и е ~}$ знака несколько учащается после 40-го листа): йжє 15, 42, 73, 79 об. (bis), 114, 121, 121 об., 122, 153 и др., йжє 47, йхъжє 69 об., 168 об., йхъ 107 об., 213 об., й 133 об., є́жє 83,151, 197, ймъ 155 , ѓжє 168; но возможно и над начальной гласной других

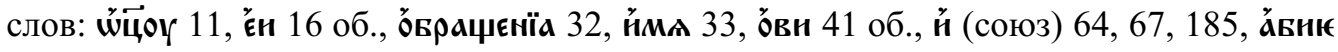

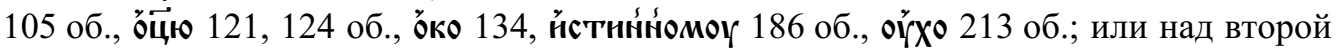
из двух букв, передающих гласный: вєзаконї 65.

Камора изредка появляется как знак ударения (несколько активизируясь со 150-х лл. после вставки 4-го почерка, особенно почему-то в словоформах с основой въньц-):

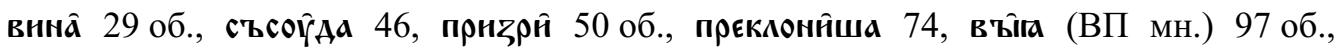

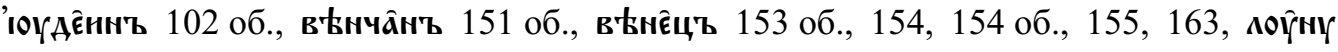
156 об.; встречается над союзом но: ноิ 26 об., 67 об., 153 об. Реже наблюдаются примеры в неакцентной функции - над второй из двух гласных: моаิ 28, въдый 78 об.; возможно и над согласным (как знак пропущенного редуцированного?):

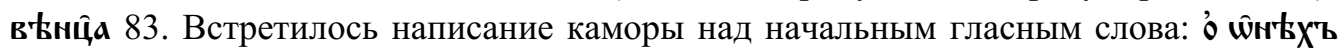
203, เа̂кw 203 об. Ближе к концу кодекса (со 190-х лл.) она начинает появляться только над односложными словами с гласным о: ноิ 184, 194, 200, 203 об., 212 об.,

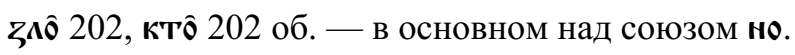

Вария впервые появляется на л. 46 об. (нмй, и далее последовательно ставится в этом союзе) и используется как акцентный знак: вина̀ 47, ócкаво̀y 48, ннжѐ 48 об., 168 об., 205, но необязательно над конечной гласной: ннд̧па̀дшага 56, самойла 167 об., потайною 211 ; в качестве неиктусного знака может употребляться над на-

\footnotetext{
${ }^{4}$ Такое терминообозначение, принятое в работах М. Г. Гальченко, не вполне точно, поскольку кендема в строгом смысле - это знак двойного грависа, противопоставленный двойному акуту [Загребин 2006: 28]. Однако для древнерусского материала, и в частности для Син. 675, это оправдано, поскольку в рукописи написание этого знака отличается нестабильностью. Он может выглядеть (чаще всего в Син. 675) как две точки над буквой, как двойной акут или гравис, и даже как двойной знак придыхания при одинаковом наборе функций.

5 Это основная функция данного знака в почерках, ориентирующихся на новую южнославянскую норму: «В древнерусских рукописных книгах конца XIV — начала XV в. из всех акцентных знаков наиболее рано и регулярно начинает использоваться именно кендема над односложными словами» [Гальченко 2001: 119].
} 
чальной (неприкрытой) гласной слога: а̀врад̀ма 167 об., ’а̀рú́на 211 (ср. также, повидимому, декоративное употребление над первой из гласных: мйа́мєдовъ 211, мйámєдова 214 об.); встречается также над односложными словами: вѝ 54 об.

Реже других знаков в Син. 675 появляется великий апостроф. Ближе к началу рукописи он в единичных примерах пишется над начальной гласной слова/слога: прєдаюцаго й 10 об., ї того, овша̊ 23 об.; после л. 200 он дважды встретился над союзом: ’’ 203 об., 213.

Примеры показывают, что, при наличии в Син. 675 всех возможных диакритических знаков, их функции оказываются не до конца установившимися и в разной степени факультативными. У наиболее частых в рукописи оксии, варии и исо есть устойчивое базовое употребление, связанное с передачей ударения в слове ${ }^{6}$, но при этом они иногда встречаются и не как показатели ударения: они могут выступать в функции придыхания (а́щє, а̀врах̀мa - над начальной гласной слова в Син. 675 достаточно регулярно используется знак' или , см. 2.2.1.3) или как показатель односложного слова (вẃ, кѝ); оксия и исо используются над второй из двух гласных подряд (мрї̈а́, вєзаконї̌); оксия также, возможно, использована в функции паерка ('іверѓшн).

Больший разброс функций характерен для более редких каморы и кендемы: они могут маркировать односложные слова, стоять над начальной гласной, над второй из двух гласных. Друг от друга их отличает, видимо, только возможность использования каморы как акцентного знака в редких случаях. Явно маргинальным знаком для писцов рукописи является великий апостроф.

Несмотря на непоследовательность, использование акцентных знаков в рукописи является важным орфографическим признаком для периода конца XIV в. Как отмечает М. Г. Гальченко, «'южнославянизмы' в древнерусских рукописях конца XIV начала XV в. могут употребляться непоследовательно, а некоторые из них - даже окказионально; существенно само их наличие, строгая норма в их употреблении может отсутствовать» [Гальченко 2001: 124]. Полный набор акцентных знаков фиксируется Гальченко в единственной рукописи XIV в. (Слова Василия Великого, 1397 г.?, переписана на Афоне); стабильным же его применение становится только в почерках с 10-х гг. XV в. Таким образом, Син. 675 как рукопись рубежа XIV$\mathrm{XV}$ вв., переписанная на Руси, может считаться одной из ранних попыток ввести в норму новую систему диакритических знаков.

\footnotetext{
${ }^{6}$ В связи с этим рукопись представляет большой интерес для дальнейшего акцентологического исследования. Анализ всей совокупности акцентированных форм помог бы определить, какой из акцентных систем придерживались переводчики Евхология - древнерусской или южнославянской. В случае, если была использована древнерусская акцентуация, рукопись Син. 675 при наличии лишь единичных акцентированных памятников XIV в. могла бы стать важным источником по реконструкции древнерусского ударения.
} 


\subsubsection{3. Использование знака придыхания}

О знаке придыхания М. Г. Гальченко пишет, что «его частое употребление наблюдается в древнерусских рукописях с эпохи 2-го ЮСлВ» [Гальченко 2001: 173$]^{7}$.

Этот диакритический знак хорошо представлен в Син. 675. Его внешний вид в рукописи отличается нестабильностью. Чаще всего он имеет округлую форму и концами дуги обращён влево, но используется и зеркальный вариант такого начертания, и - в редких случаях - с дугой, обращённой концами вверх, а также возможен вариант угловатой формы - обращённый как влево, так и вправо ${ }^{8}$.

Придыхание ставится в основном почерке Син. 675 над большинством началь-

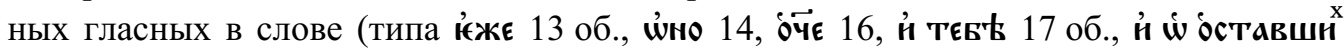
19 об., архндїакш 22 об., и йзмн 39 об., адова 57 об. и т. п.), по сравнению с другими гласными оно ставится гораздо реже над начальным or (oíma 15). Менее последовательно, но всё же часто пишется знак над гласными, начинающими слог: измнавъ

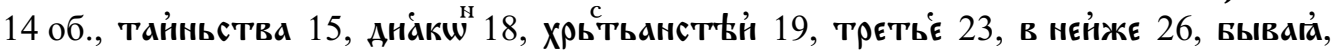
по аммїнЊ 28 об., таитьса 39, твоікї 41 об., нейъһчтена 65 об.

Частный случай представляет собой регулярное употребление повтора значка придыхания при соседстве двух букв м. В большинстве случаев над м используются

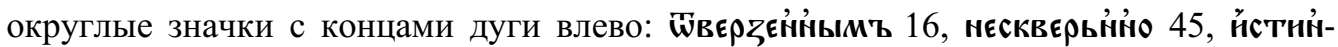

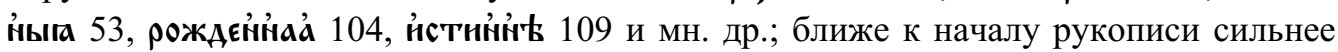
заметна нестабильность этих написаний - знаки могут быть обращены вправо, вместо них (обоих, или только вместо второго) может стоять другой диакритический

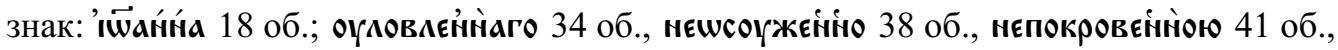
нєповнініню 60 об.; кроме того, оба значка могут «съезжать» на второе н, становясь более похожими на кендему: пространӥоє 23 об. В редких случаях также двойное м пишется безо всякой диакритики (избраннымъ 37 об., сдыганный 57).

\footnotetext{
${ }^{7}$ Исследовательница не вполне оправданно называет его паерком. При этом собственно паерок в Син. 675 также используется, хотя и в редких случаях. Он графически отличается от тех символов, которыми в рукописи обозначается придыхание: имеет угловатое начертание, повёрнут развилкой влево или вниз и влево; может быть также z-образной формы. В начале рукописи паерок

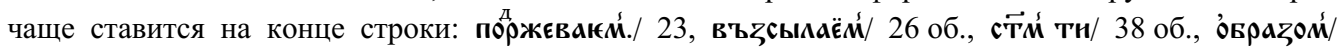
39 об.; с 40-х листов начинает встречаться в приставках на -z: нұ́ноүтрн 46, ннц́поскн 51, 55,

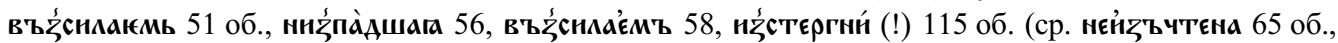

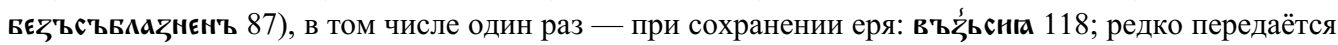
утраченный редуцированный в других условиях: соүєтс́тввоr 113. Отмечен также пример, когда паерок стоит над буквой ь: ЗаБмоүжАь́шєё 27.

8 Эти три графические модификации знака в южнославянских диакритических системах соответствуют трём разным сущностям. Для сербских рукописей релевантным является различение знаков ' («псила»), '(«дасия») и “ («врахия») [Загребин 2006: 27-28]; но на русской почве эти обозначения смешиваются, в связи с чем можно обозначить их в целом как знак придыхания.
} 
Один раз, по-видимому, вследствие отмечавшегося в 2.2.1.2 смешения функций ударений и придыхания, знак поставлен вместо ударения: вы́ю 17 об. Видимо, по ошибке поставлено придыхание над согласным в примере: iє⿲㇒丨丶 59.

\subsubsection{4. Употребление $\boldsymbol{a}=[\mathrm{ja}]$ и or $=[\mathrm{ju}]$}

Написание а в соответствии с [ja] - один из наиболее ранних новых южнославянизмов, легко входивших в древнерусскую орфографию уже с конца XIV в. [Гальченко 2001: 135, 160]. По сравнению с ним однотипная орфограмма - использование or вместо ю после букв гласных - заметно более редкое явление; оно обычно представлено в отдельных почерках единичными примерами [Там же: 161, 239, 264].

Основной почерк Син. 675 отличается от исследованных Гальченко иным соотношением орфограмм с а и с оr. Последовательнее он использует всё же $\mathbf{a}=[\mathrm{ja}]$, но при этом написания or $=[\mathrm{ju}]$ у него нельзя назвать единичными. Представим количественные данные, показывающие взаимоотношения двух орфограмм в Син. $675^{9}$ :

Таблица 1

$a=[j a]$ и or $=[$ ju] в основном почерке Син. 675

\begin{tabular}{|c|c|c|c|c|}
\hline после буквы: & a & ra & or & 10 \\
\hline H & $43 \%(32)$ & $57 \%(42)$ & $34 \%(14)$ & $66 \%(27)$ \\
\hline$\underline{\pi}(1)$ & $98 \%(156)$ & $2 \%(4)$ & $64 \%(32)$ & $\underline{36 \%(18)}$ \\
\hline $\mathbf{b}$ & $44 \%(4)$ & $56 \%(5)$ & - & $100 \%(12)$ \\
\hline ы (ы) & $14 \%(13)$ & $86 \%(79)$ & - & $100 \%(3)$ \\
\hline a & $45 \%(56)$ & $55 \%(68)$ & - & $100 \%(54)$ \\
\hline b & $48 \%(12)$ & $52 \%(13)$ & - & $100 \%(32)$ \\
\hline $0(w)$ & $36 \%(29)$ & $64 \%(52)$ & - & $100 \%(69)$ \\
\hline$\epsilon$ & $32 \%(7)$ & $68 \%(15)$ & $8 \%(2)$ & $92 \%(24)$ \\
\hline $10 /$ or & $-{ }^{10}$ & $100 \%(12)$ & $5 \%(3)$ & $95 \%(52)$ \\
\hline
\end{tabular}

При рассмотрении приведённых в Таблице 1 данных бо́льшая активность $\mathbf{a}=$ [ja] заметна и по проценту новых написаний после разных букв гласных, и по количеству букв, после которых последовательно применяется орфограмма. Отсутствие йотации на письме перед [а] возможно в почерке после любой буквы гласного; напротив, or $=[\mathrm{ju}]$ используется в Син. 675 последовательно только после букв, передающих [i]. Ограниченность данной позицией ожидаема в свете данных рукописей, исследо-

${ }^{9}$ Подсчёты в Таблице 1 сделаны на основе сплошной выборки из двух отрывков текста лл. 7-61 и лл. 187-217; не учитывались примеры с необозначенной йотацией в корнях заимствованных слов (типа днаконъ, Хрнстнаньск-, ноҮ(Ає), представленные в древнерусской письменности с древнейшего периода [Успенский 2002: 308]. И далее в 2.2.1.4 и 2.2.1.5 речь идёт только об орфограммах, не относящихся к корням в заимствованиях.

10 За пределами рассмотренных отрывков встретилось написание с оуа: оүазвєна 136. 
ванных М. Г. Гальченко: в них оy = [ju] также встречается почти исключительно после букв н, ї [Гальченко 2001: 161, 199, 204, 210, 219]. В редких случаях орфограмма отмечается после других букв: єкнссєоя, мййсє8 (в заимствованиях), товшой [Там же: 80, 199]. При исключительности таких написаний примечательно наличие редких примеров после є и ю / or в Син. 675; вот их полный список в учтенных в Таблице 1 пределах (лл. 7-61, 187-217): ст̈оуоу 15 об., монсеоу 16, назнаменноуюцюоу

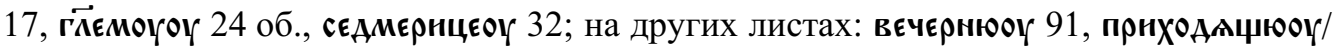
92, про/шедъшюог 114 об.; встретился также пример с сочетанием ьог: Б̈तгогтровь/ог 91 об.

Таким образом, употребление oy = [ju] в Син. 675 выделяется на фоне других рукописей в первую очередь в количественном отношении: в базовой для этих написаний позиции после буквы, передающей [i], [ju] чаще передаётся новым, а не традиционным способом. Обратим внимание на то, что эпицентр инновационных написаний приходится на позицию после графемы ї, которая сама по себе является орфографической инновацией конца XIV в. (см. 2.2.1.5). Подчёркивают этот факт и данные по [ja]: написания иа в процентном отношении не выделяются на фоне $\mathbf{d a , ~ b a , ~}$ ka; зато написания їа проведены в почерке почти со 100\%-ной последовательностью. В совокупности факты показывают, что фактором, существенным для орфографической системы, представленной в Син. 675, является соседство нескольких орфограмм в словоформе. На тех участках, где оно присутствует, новая орфография применяется последовательнее.

На материале орфограммы $\mathbf{a}=[\mathrm{ja}]$ сделанное наблюдение о совмещении нескольких орфографических приёмов подтверждается ещё одной особенностью. М. Г. Гальченко замечает, что во многих почерках рассматриваемого периода над $\mathbf{a}=[$ ја] ставятся надстрочные знаки [Гальченко 2001: 199]. Уже приводившаяся в 2.2.1.2 группа примеров с оксией вместо знака придыхания над а (нмєнованіа́,

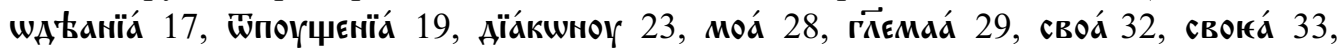
моукавьстїа 117, вражїа́ 123, мрї̈а (РП) 169) ${ }^{11}$ может быть понята как попытка дополнительной (надстрочной) маркировки новых написаний.

Показательна динамика использования описанных орфограмм в рукописи. Она показывает, что к концу рукописи необозначение йотации после ї происходит заметно последовательнее, чем в начале. В первом рассмотренном отрезке (лл. 7-61) отмечено 31 сочетание на и 73 - їа (30\%/70\%); на последних же 30 листах рукописи соотношение резко меняется в пользу более болгаризированного - всего 1 раз на (несъмнанн' 199) и 83 раза їа $(1 \% / 99 \%)^{12}$. То же соотношение действует и для

${ }^{11}$ Написания с придыханием над $\mathbf{a}=[\mathrm{ja}]$ не так показательны, т. к. знак придыхания в Син. 675 возможен над любой гласной, открывающей слог; но для дополнительного выделения нового написания может использоваться любая диакритика, ср. соседство в одной строке форм: твог, но твоӓ 65 об.

12 Заметим, что для написаний ига и їга подобного не наблюдается. 
noy / їоу: в первом отрывке они соотносятся как 52\% / 48\%, а во втором — как 5\% / 95\%. Сходная активизация употребления наблюдается только для сочетания аd (в первом отрывке ага примерно вдвое чаще, чем новое ad, а во втором ага уже примерно в четыре раза реже, чем аa). Одновременно с этим другие сочетания двух гласных с необозначенным между ними йотом напротив - снижают активность к концу рукописи (\$a, ыa) или совсем исчезают (ba, roor, orfor, forf).

К концу рукописи писец отчётливо следует принципу записывать сочетания звуков [ija] и [iju] (в меньшей степени [aja]) по новой орфографии; объединение написаний после ї в единую орфограмму, по-видимому, обуславливает необычную частотность oy $=[\mathrm{ju}]$ в рукописи. Исключения для [ija] писец делает в основном на стыке приставки и корня - в основе прнгат-. Пропуск йотации на письме между других гласных звуков при этом становится менее обязательным.

Дополнительно характеризуют активность орфограммы с необозначением йота на письме аномальные написания на её почве, встретившиеся в рукописи несколько раз. В таких случаях по ошибке подряд пишутся оба варианта записи [ja]/[ju]: препогадсавса 10, инаага 57 (возможно, также проклАтн_оу < *проклАтнюоу 34, затёртую букву плохо видно).

\subsubsection{5. Использование ї перед буквами гласных}

Согласно данным «Сводной таблицы графико-орфографических данных» [Гальченко 2001: 386-420], последовательное использование ї перед буквами гласных встречается со второй половины 90-х гг. (самый ранний памятник - Киевская псалтырь 1397 г., тексты подписей к рисункам), но обычным (регулярным в большинстве почерков) становится только в 10-х гг. XV в. Использование данной орфограммы в Син. 675 объединено общей тенденцией с орфограммами, рассмотренными в 2.2.1.4, более последовательного употребления к концу рукописи.

Буква ї (в редких случаях І, в основном при наличии над ней диакритики) используется в Син. 675 перед а, га, н, ю, оя, є, к; при этом перед га (видимо, в связи с рассмотренной в 2.2.1.4 комбинированной орфограммой їа) ї-десятеричное появляется редко. Конкуренция ї с графемой н в начальной части (лл. 7-61) и в конце рукописи (лл. 187-217) представлена в виде таблицы:

Таблица 2

и / ї перед буквами гласных

\begin{tabular}{|l|l|l|l|}
\hline & лл. 7-61 & лл. $187-217$ & всего \\
\hline $\mathbf{H}$ & $238-56 \%$ & $58-24 \%$ & $296-44 \%$ \\
\hline$\ddot{i}$ & $184-44 \%$ & $187-76 \%$ & $371-56 \%$ \\
\hline
\end{tabular}

Заметный прирост написаний с ї на последних листах Син. 675 связан во многом с активизацией сочетаний їа и їоя (см. 2.2.1.4); также учащается написание їє, хотя и остаётся в меньшинстве по отношению к иє. 
Новая функция ї, связанная с позицией в слове, ещё совмещается в Син. 675 с его использованием на конце строки (єүмї 22 об., прї//Аєжномог 23 об.-24, двї/жютсА 65 об., рукї/ 68, твої/мъ 75 об. и др.), или близко к концу строки, при необходимости уместить слово (єАїнъ/ 70, молїмса// 76, мїръ/ 154 и т. п., особенно в заголовках: маттвы кїтин́ы́ ї вєлїкога вєрнї./ 18); также буква употребляется между согласными, чаще в заимствованиях (на пїцю 63, мїтогргїн, прокїмєнї/ 95, мєкХїсєАєкъъ 202, көмї/нъ 203, єрмогөйиъ 204 об. и др.).

Встретилось несколько аномальных написаний на основе нового правила дистрибуции н/ї, однотипных отмеченным в 2.2.1.4. В таких случаях обе буквы используются для передачи [i] одновременно: 弓ूравнї̈ 19 об., оүгоднїоч 42 об. В обоих примерах двойное и соседствует с орфограммой пропуска йота.

\subsubsection{6. жА (ж⿱⺈) в соответствии с *dj}

Южнославянский вариант оформления рефлекса *dj становится основным уже в отдельных рукописях 90-х гг. XIV в. [Гальченко 2001: 388]. В орфографии Син. 675 представлен переходный этап к новому написанию *dj: вариант жА преобладает, однако примеры традиционных для XIII-XIV вв. написаний не единичны. Всего в основном почерке рукописи ${ }^{13}$ отмечено 127 позиций с рефлексом $* \mathrm{dj}$, из них жА (ж) $)^{14}$ использовано в 87 примерах (68,5\%), а ж- в остальных 40 (32,5\%).

Два варианта написания *dj в Син. 675 , хотя и не до конца последовательно, вступают в дистрибуцию, которая отражает ступенчатый характер становления новой нормы. В отдельных комбинациях морфем и в некоторых лексемах соотноше-

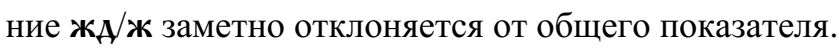

Писец Син. 675 последовательно использовал новое написание в существительных с суффиксом -ениј-: в этой группе последовательно используются написания жА (более 20 раз) за двумя исключениями, расположенными на соседних листах: овьХожєньга 156 об., нахожєнь/г 157 об. Эти два примера выделяются на фоне всех остальных лексем с тем же суффиксом ещё по одному параметру: только в них представлен некнижный вариант суффикса, -еньј- вм. -ениј-. Кроме того, отметим, что именно на базе группы написаний с -ениј- в Син. 675 появляются гиперкорректизмы: въовражАє/нїог 113 об., въ/овраждєнню 174 об.; один раз также исправленный: въовраж_єнїє 208 (ср. аналогичные примеры - [Гальченко 2001: 99, 119, 123, 204]).

Вероятно, таким же обязательным было применение нового написания на конце слова, ср.: внждъ 134 об., надєждъ 137 об., внждь 151 об., Ааждъ 163, 189 об. (контрпримеров не встретилось). В последовательном использовании жА писец мог

${ }^{13}$ Для этой и рассматриваемых ниже орфограмм точные количественные данные приводятся для всего переписанного основным почерком текста рукописи.

14 Отметим также встретившийся дважды вариант этого написания жьд, используемый при переносе: тогжь/Аага 106 об., порожь/Аєнїа 181. 
ориентироваться также на лексический фактор: слово өАєжАव шесть раз встретилось только в таком виде.

Обратное правило - сохранять традиционное ж - опиралось на лексический фактор. Без исключений из этого правила, т. е. постоянно с ж, в Син. 675 пишутся слово могжа (11 фиксаций) и корень жаж- (жажаџага 44, жажєю 161). При общем предпочтении жА в рукописи заметно выделяются также предлог-приставка прєжє (7 раз ж / 4 раза жА); наречие ${ }^{15}$ нєосоужєнно (5 раз ж/ 1 раз жА). В остальных лексемах / основах написания через ж единичны при преобладающих с жА.

Можно сделать вывод, что присутствие в орфографии главного писца Син. 675 обоих вариантов оформления рефлексов *dj опирается в заметном числе случаев на частные правила. Традиционное ж ещё сохраняет за собой ряд основ, и по этой причине не устранено полностью из орфографической системы. Однако в большинстве возможных позиций писец уже использует южнославянский вариант написания. Единое соотношение вариантов жА/ж выдерживается на протяжении всей рукописи.

\subsubsection{7. Написания с удвоением м}

Двойное м в формах страдательных причастий прошедшего времени, в отличие от рассмотренных выше языковых особенностей, своим происхождением не связано непосредственно с южнославянскими написаниями. По мнению А. И. Соболевского, эти формы «сравнительно новы и обязаны своим происхождением влиянию отпричастных прилагательных на ньнъ», свойственных и южно-, и восточнославянским языкам. Собственно причастия с -нн- (-ньн-) отмечаются в древнерусских письменных памятниках в небольшом количестве со второй половины XIII в. [Соболевский 1907: 262-263]. Заметную активизацию причастий на -нн- исследователи отмечают в более поздний период - XIV-XV вв. [Кузьмина, Немченко 1982: 380]; и особенно «удвоенные написания входят в моду» с XV в. [Осипов 2010: 132]. Материал Син. 675 позволяет рассматривать удвоение н как орфограмму, однородную с рассмотренными выше, по нескольким показателям.

Во-первых, удвоение проведено основным писцом с той же степенью последовательности, что и отдельные южнославянизмы (написания їа, жА на месте *dj, использование знака придыхания). Пассивные причастия с одной м в суффиксе встречаются редко, отмечено восемь таких примеров: оуГОтовлєнЊн, прєАоцГотовлєноу 8 об., вЪвЊреный 128, скверненаго 173 об., сЖеЖе́нЫХЪ 175 об., вЪаконєнаа 177, Преданоую 207 об., свершєною 216; ср. МНОГОЧИСЛОННЫО форМЫ С УДВоеНИеМ: оуго-

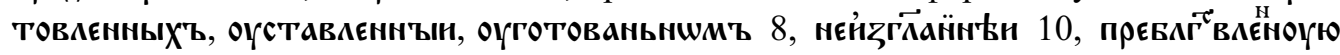

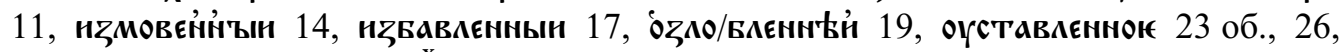

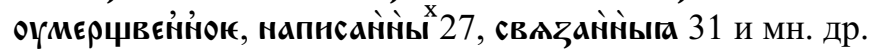

Во-вторых, регулярнее других орфограмм написание нн маркировано в рукописи с помощью диакритики (см. подробнее в 2.2.1.3).

${ }^{15}$ Именно наречие, т. к. в других формах с тем же корнем (-сољ(-) преобладают новые написания. 
И в-третьих, хорошо показывает инновативность использования удвоения большое количество гиперкорректных написаний на его основе. Если в предшествующий период письменности аналогии с прилагательными на -ньн- подвергались только причастия, то писец Син. 675 может удвоить м в гораздо большем числе позиций. Подобные новые удвоения отмечены:

- в прилагательных, не производных от причастия (в том числе уже имеющих две н подряд, так что образуется последовательность из трёх н со вставками букв

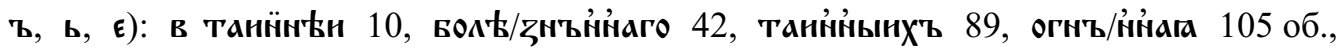
огне/н̈ныХ'ъ 119, оүйныга 161, тайнад 209 об.; основная часть написаний с дополнительным м в прилагательных приходится на частотную лексему (нє)достоннын: нЕАОстОНННЫМЪ 16, 67, 137 об., нЕАОстОНнНЫХไЪ 26, 84 об., 88 об., 163, 185, нЕАОстО-

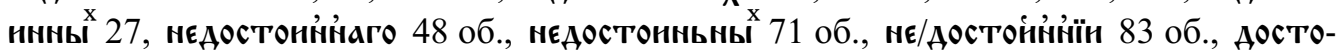

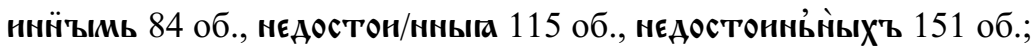

- в причастиях, в основе которых есть последовательность -єн-, не относящаяся

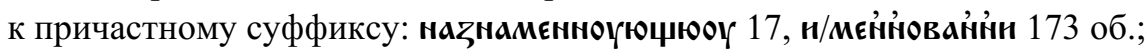

- в наречиях: Б्रГогов Вннно 9 об., сквернно 38, Аостониіно 67, Ао/стоннӥ' 109 об., неогченін' 211;

- в существительных: во нстннноу 67, 215, нстн/нi't 109, нстниною 169 ,

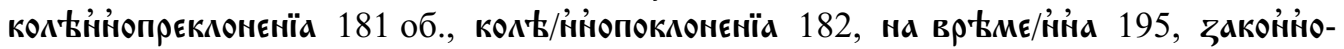

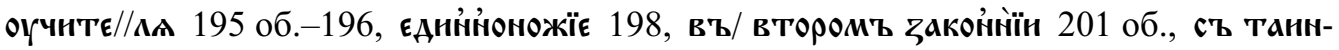
ннкы 209 об., нстнініа 217;

- в местоимениях: нннад 79, 162, 170 об., нины 133;

— тройное н в пассивном причастии: покровєнъиंногу 195 об.

Рассмотренные особенности написаний с удвоением м показывают, что данная орфограмма стоит в одном ряду с рассмотренными ранее чертами и, по всей видимости, её резкая актуализация в почерке Син. 675 связана со 2-м ЮСлВ. Мы рассмотрели эту орфограмму вместе с признаками минимального набора, поскольку подобно им удвоение реализуется писцом в том числе гиперкорректно: сам писец, по-видимому, оценивает эту орфограмму как один из базовых приёмов новой орфографии. Написания Син. 675 показывают, что, несмотря на наличие предпосылок к появлению двойного н в причастиях на русской почве, для книжника рубежа XIV$\mathrm{XV}$ вв. такое употребление ассоциировалось прежде всего с южнославянским узусом.

\subsubsection{8. Написание приставок на ъ-}

Привлекает внимание в Син. 675 ещё одна орфографическая позиция, в которой оказываются возможны гиперкорректизмы. В древнейшей орфографической норме перед корнем, начинающимся на свистящий щелевой, приставки на з- теряли свой конечный согласный; примеры восстановления выпавшего согласного приставки известны уже с конца XII в., однако в течение XIII-XIV вв. новые написания продолжали конкурировать со старыми, не обозначавшими согласный приставки [Со- 
болевский 1907: 147]. Материал Син. 675 показывает, что 2-е ЮСлВ могло быть дополнительным фактором в процессе утверждения в норме новых написаний.

Для писца рукописи одним из действующих орфографических правил было восстановление конечного согласного приставки на $\mathbf{3}-\mathbf{c}$ - (или первого согласного сле-

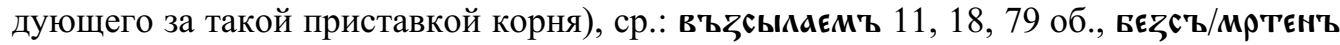
33 об., разстоюцнхъ 73, въ/зстави 88, разстогателное 111 и др. О специальном внимании к данной орфограмме свидетельствует небольшая группа написаний (пять примеров) с незакономерным дополнительным $\mathbf{c} / \boldsymbol{\zeta}$ перед корнями, не начинающимися на свистящий: въз́спрнноснмъ 51 об., вє乙ьскро/вныга тн жертвы 71 об.,

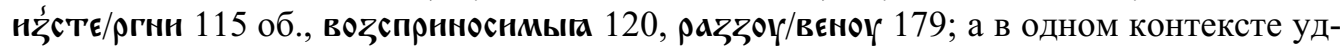

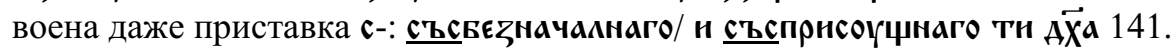

\subsubsection{9. Общая характеристика рассмотренных орфограмм}

Практически все рассмотренные выше признаки в Син. 675 сопровождаются возникновением гиперкорректизмов и других аномальных написаний на их почве. Это, на наш взгляд, говорит об их одинаковом статусе: эти черты были единовременно и сознательно введены в систему написаний; именно на эти участки орфографической системы переписчик рукописи обращал внимание в первую очередь - к ним нужно было применять инновационную систему правил. По-видимому, такой широкий спектр нововведений был использован с целью маркировать текст, язык которого соответствует новым переводческим стандартам.

\subsection{2. Расширенный минимальный набор}

Минимальный набор южнославянских признаков расширяется, по наблюдениям М. Г. Гальченко, за счёт трёх особенностей: 1. Употребление буквы $\mathbf{S}(\boldsymbol{2})$ и/или $z$ в звуковом значении $[\mathrm{z}] .2$. Написание рефлексов $* t ъ r t$ с редуцированными после плавного; при наличии явных южнославянизмов в почерке в качестве признака можно рассматривать также написание рефлексов *tert через $\mathbf{b} .3$. ь вместо ъ на конце слов после твёрдых согласных [Гальченко 2001: 291].

Звук [z] в Син. 675 передаётся только при помощи з. 2-й и 3-й признаки в почерке присутствуют в разной степени. Связанный с написанием еров 3-й признак оказывается наиболее актуальным в почерке из расширенного набора, что подчёркивается и другими особенностями в передаче букв редуцированных, противопоставленными традиционной древнерусской орфографии ъ и ь. В связи с этим данные по особенностям употребления еров в целом в Син. 675 будут рассмотрены вместе в настоящем разделе.

\subsubsection{1. Написание рефлексов *tъrt и *tert}

Древнерусские рукописи с преобладанием написаний типа tръt на месте *tъrt появляются уже во вт. пол. 90-х гг. XIV в. [Гальченко 2001: 388]. Основной же писец 
Син. 675 их употребляет редко и только в одном слове: ваъхвованєн 191 об., вАъ/Хвованїємъ 202 об., вАъХвованїа 206 об. То же слово всё же чаще пишется основным для писца способом: волхвованїа 197, волхво/ванмн 203, 203 об., волхвованїог 213. Абсолютно преобладают у него закономерные для XIV в. русские написания, отражающие прояснившийся редуцированный, напр.: нсполннтн 8, 30,

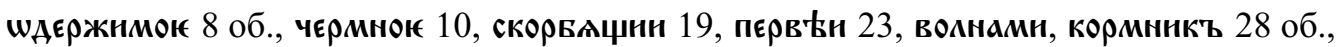

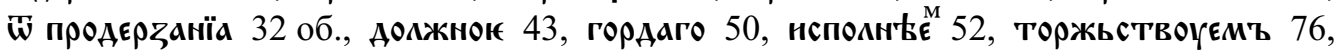
четвертоГЪ 89, волкоХицнок 136, вєZмолвно 153, держава 163 об. и мН. др ${ }^{16}$. Кроме перечисленных вариантов записи, один раз использовано восточнославянское напи-

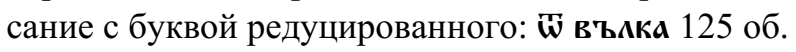

Орфография рефлексов *tert в Син. 675 допускает вариативность, однако незначительное количество написаний с $\mathbf{b}$ после $\rho$ не выделяет рукопись на фоне традиционного для XIV в. употребления ${ }^{17}$ и скорее говорит о том, что в этом отношении писец не пытался использовать новую орфографию. Большинство ятевых написаний

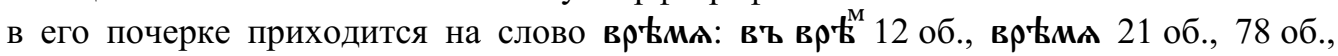
97 об., 106 об., 109 об., 159 об., 160 об., 161 об., 180 об., 190 (bis), на врьмена 159, 160, на врьмєнна 195 (при этом чаще - 19 раз, т. е. в 56\% случаев - данный корень всё же пишется через $\boldsymbol{\varepsilon}$ ). В единичных примерах южнославянское написание встретилось

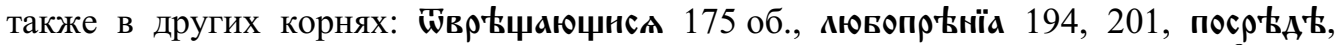

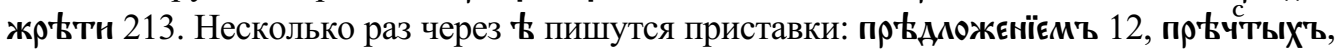
прtстымъ 162, прқчнстыхъ 162 об. (через є встретилось более 150 написаний).

Признаки расширенного набора использовались в русской письменности реже, чем рассмотренные в 2.2.1, особенно на раннем этапе 2-го ЮСлВ. Однако помимо этой общей закономерности в системе основного писца Син. 675 существовали дополнительные факторы, которые препятствовали активному применению рt в рефлексах *tert. При введении его в систему написаний слог рt оказался бы в его орфографии перегружен, передавая сразу три разных звучания: $\rho \mathbf{t}=$ [r’ě $]$ (напр., $\rho \mathbf{k \kappa a )} ; \boldsymbol{\rho} \mathbf{t}=\left[\mathrm{r}^{\prime} \mathbf{a}\right]$

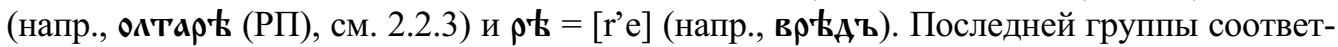
ствий писец мог избегать, что и препятствовало усвоению новой орфограммы. Из двух книжных реализаций слога $\rho \mathbf{t}-\left[\mathrm{r}^{\prime} \mathrm{a}\right]$ и $\left[\mathrm{r}^{\prime} \mathrm{e}\right]-$ был сделан выбор в пользу первой.

\subsubsection{2. Особенности употребления букв ъ, $\mathbf{b}$}

Древнерусские рукописи, в которых писцы последовательно выдерживали бы среднеболгарское распределение двух еров, до сих пор неизвестны. Из болгарских

${ }^{16}$ Написания типа Аєрь/жа 23 об., оутверь/Ан 35 об., нсполъ/ни 131 об. используются при переносе с одним исключением: пєрьсть 214. Единожды также встретилось написание без гласного: Безсъ/Мртенъ 33 об.

${ }^{17} \mathrm{Cp}$. замечание М. Г. Гальченко о том, что написания рt на месте *tert «имеются в древнерусских рукописях середины XIV в.» [Гальченко 2001: 291]; об ином развитии орфографии написаний *telt на русской почве см. [Живов 2006]. 
рукописей усваивается в первую очередь употребление конечного ь после твёрдых согласных [Гальченко 2001: 87, 122, 204, 250], при этом «наиболее легко это происходило в тех случаях, когда такие написания не препятствовали смыслоразличению и не противоречили языковому сознанию древнерусских писцов, для которых противопоставление согласных по твердости-мягкости было фонологически значимым» [Там же: 87]. В связи с этим в рукописях, исследованных М. Г. Гальченко, незакономерный ь появляется чаще всего после букв к, г, Х, в, м.

В Син. 675 ь после конечного твёрдого звука спорадически встречается на всём протяжении рукописи на фоне основного традиционного варианта. Маргинальный статус этой орфографической черты в системе написаний основного почерка Син. 675 подчёркивается тем, что в некоторых случаях незакономерный ерь исправлен теми же чернилами на ъ (с помощью надстрочного уголка). Количественные данные по не-/исправленным написаниям конечного ь представлены в таблице:

Таблий 3

Буква ь после конечного твёрдого согласного

\begin{tabular}{|c|c|c|}
\hline после & b & $*_{\mathbf{b}}>\mathbf{b}$ \\
\hline M & 20 & 2 \\
\hline H & 12 & 4 \\
\hline B & 8 & 1 \\
\hline$X$ & 6 & 2 \\
\hline$\kappa$ & 5 & - \\
\hline c & 3 & 1 \\
\hline$\Lambda$ & 3 & 2 \\
\hline $\mathbf{T}$ & 2 & 3 \\
\hline A & 2 & 2 \\
\hline $\boldsymbol{r}$ & 1 & 2 \\
\hline E & 1 & - \\
\hline
\end{tabular}

Чаще всего ь появляется после твёрдого м, что закономерно по причине усвоения неэтимологических конечных -мь из старославянской письменности ещё в древнейший период ${ }^{18}$. Но следующая по частотности позиция - после м - является, по-видимому, индивидуальной особенностью писца Син. 675, т.к. обычно в этой позиции неэтимологический «болгарский» ь появляется реже, чем после в и заднеязычных [Гальченко 2001: 87]. В целом же этот болгаризм занимает периферийное положение в системе писца, по болгарской норме пишется около процента соответствующих позиций (например, для к - пять болгаризированных написаний при 448 конечных позициях слога къ, для $X$ - восемь при более 1000 конечных позиций в тексте Евхология и т. п.).

${ }^{18}$ Ср., напр., 16 форм ДП мн. ч. на -мь в Погодинском евангелии ХІ в. [Мольков 2016: 242]; 18 подобных форм — в Чудовской псалтыри ХІ в. [Обнорский 1912: 356]. 
Непоследовательность в использовании данной южнославянской орфограммы в рукописи может быть обусловлена другой орфографической особенностью почерка. При написании конечных редуцированных писец ориентируется в отдельных случаях и на противоположное правило: писать ъ после мягкого в древнерусском языке конечного согласного. В основном это относится к написанию словоформы єсть. В 2,5 раза чаще, чем єсть, в Син. 675 используется запись єстъ (кст”), и в последней трети текста (после л. 153) писец переходит исключительно на написание с -ъ. Это правило распространяется и на другие атематические формы 3 л. ед.ч. наст.вр.: пропов Һст"ъ 31, вЊст"ъ 178 об., 186 об., нспов 'ст"ъ 180 об., а один раз использовано даже в существительном: чєст’ъ 37 об. ${ }^{19}$ Написание єст” влияет и на орфографию производного существительного: слово єстьство в этимологическом виде встретилось всего один раз (на л. 76), во всех же остальных случаях оно пишется как єстьство $(8 \text { раз })^{20}$.

Так же последовательно с неэтимологическим ъ пишется в Син. 675 ИП ед. ч. местоимения сь - в виде съ (без исключений). Во избежание путаницы с омографичным предлогом над формой местоимения во всех случаях ставится надстрочный знак: съ̈ 43, 50 об., 71 об., 82 об., 91, 101, 105 об., 113 об., 138.

Возможно, ориентация на болгарское употребление букв еров проявляется в орфографии Син. 675 ещё в одном аспекте. По-разному писец относится к написанию $\boldsymbol{E}, \boldsymbol{O}$ на месте редуцированных. В отличие от $\boldsymbol{\epsilon}$ буква $\boldsymbol{0}$ неоднократно исправляется на редуцированный ${ }^{21}$. Отмечены следующие примеры (обозначим данное исправление как Ы): прев ҚсХОАА 31 об., непретЫкновенн 47 об., сЪ сЊавшнмъ 52, в Қставн 68,

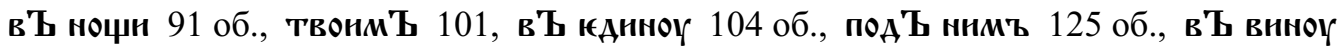
129 об., скорЫ 135 (муж. р.), звњрЫ//ства 168 об.-169, Хрїстїан' 171,

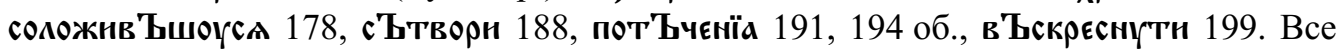
приведённые примеры относятся к исправлению в тех позициях, где в древнейший период редуцированный был слабым. При этом в Син. 675 часто наблюдаются и неисправленные написания - как о, так и є - на месте слабого ера, например: возла-

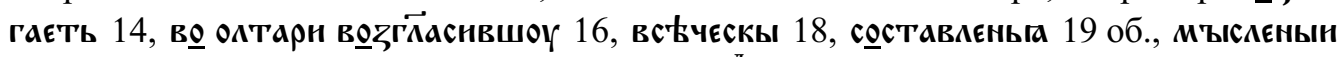

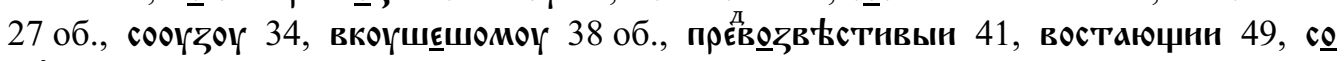

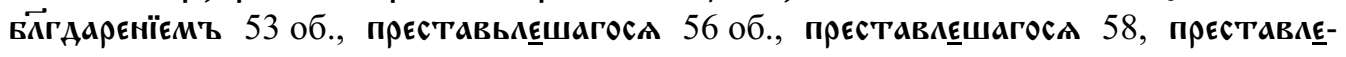

19 Эта черта связана с ориентацией на болгарские написания. Аналогичным образом при первом южнославянском влиянии написание форм глаголов атематического спряжения могло дольше других глагольных форм 3 л. сохраняться в древнерусской рукописи с конечным -ъ. Такая ситуация наблюдается, например, в Погодинском евангелии ХІ в. [Мольков 2016: 233-234], где также встречается гиперкорректное (типа чєстъ) написание существительных.

${ }^{20}$ В списке Евхология Великой церкви Син. 900 это существительное во всех случаях пишется с ь в суффиксе.

${ }^{21}$ Правка во всех случаях производится чернилами того же цвета, что и в основном тексте. Вероятно, эти исправления делались самим писцом. 


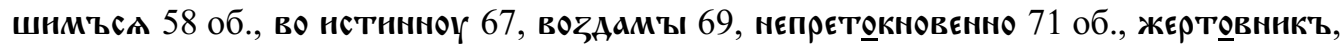

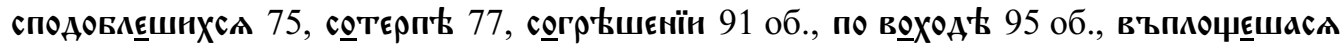

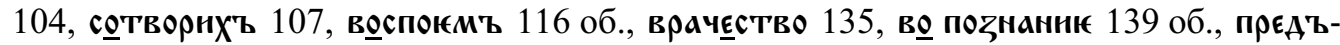

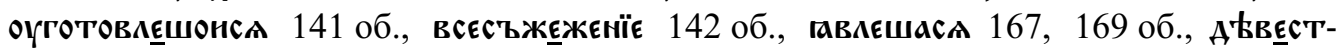

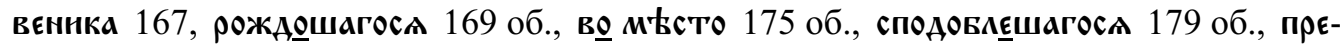

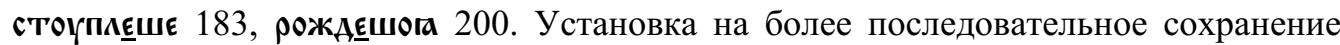
буквы ъ на месте этимологического редуцированного могла быть обусловлена употреблением восточно-болгарских рукописей, не отражающих перехода ъ $>$ 。 [Щепкин 1899: 107; Ван-Вейк 1957: 141] и имевших в соответствующих позициях написания типа въста, съоцъъ и др.

\subsection{3. Максимальный набор}

В состав максимального набора входят наиболее яркие болгаризмы, которые проникают в русскую письменность менее активно, чем рассмотренные выше особенности. К ним М. Г. Гальченко относит четыре орфограммы: 1. Употребление буквы ж. 2. Написания $\mathbf{b}=[$ ['a]. 3. Написания с ж вместо ъ. 4. Мена юсов [Гальченко 2001: 292].

Писец Син. 675 не использует $\boldsymbol{x}$, поэтому три из перечисленных особенностей его орфографической системе не свойственны. Возможно, болгарские юсовые написания отражаются в Син. 675 в написании союза мо: как отмечалось выше (см. 2.2.1.2), это слово, особенно ближе к концу рукописи, помечается знаком каморы (в виде но̄), что может быть реакцией на разное написание этого союза в русских и болгарских рукописях ${ }^{22}$.

Основной писец Син. 675 очень активно использует оставшуюся орфограмму из максимального набора - $\mathbf{b}$ в соответствии с ['a]. Эта особенность почерка обращает на себя внимание тем более, что её наличие в русской рукописи обычно обусловлено болгарским протографом [Там же: 117, 138, 151, 157, 208]. В нашем же случае 中 в болгарском значении применяется писцом по собственной инициативе, а не копируется из антиграфа. Если при этом учесть, что среди рукописей рубежа XIV-XV вв. эта особенность регулярно используется лишь в отдельных почерках (в Тактиконе 1397 г., в Лествицах 1402 и 1404 г. — [Там же: 388-394]), то её можно рассматривать как яркий индивидуальный признак орфографической системы Син. 675.

Примеры орфограммы $\mathbf{b}=\left[{ }^{\prime} \mathrm{a}\right]$ многочисленны, что позволяет сформулировать некоторые частные правила её применения. В разных словоформах, после разных согласных $\mathbf{t}=[$ [a] применяется с разной степенью последовательности. Материал Син. 675 позволяет установить, что для интеграции в орфографическую систему болгарской орфограммы при отсутствии как опоры в собственном произношении,

${ }^{22}$ В более поздних русских почерках, усвоивших букву $\mathbf{x}$, болгарское написание этого союза (нж) может также сопровождаться каморой и составлять значительную долю от всех примеров использования каморы в рукописи, в частности - в Лествице 1422 г. [Там же: 201]. 
так и возможности опираться на антиграф, писцу пришлось использовать информацию графического, морфологического, морфемного и лексического уровней. Приведём количественные данные по использованию орфограммы $\mathbf{k}=$ ['a] в виде таблицы:

Таблийа 4

Орфограмма $\mathrm{t}=\left[{ }^{\prime} \mathrm{a}\right]$

\begin{tabular}{|c|c|c|c|}
\hline после & форма & ' & A \\
\hline \multirow[t]{2}{*}{ c } & всњк- & 209 & 16 \\
\hline & Bct & 74 & 13 \\
\hline \multirow[t]{5}{*}{$\rho$} & РП ед. (муж.) & 1 & - \\
\hline & $\mathrm{B}=\mathrm{P}$ ед. & 11 & 1 \\
\hline & 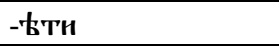 & 16 & 6 \\
\hline & импф. & 2 & - \\
\hline & в корне & 1 & passim \\
\hline \multirow[t]{10}{*}{$\Lambda$} & РП ед. (муж.) & 11 & - \\
\hline & РП ед. (жен., прил.) & 1 & - \\
\hline & $\mathrm{B}=\mathrm{P}$ ед. & 25 & 3 \\
\hline & ИП ед. (жен.) & 1 & - \\
\hline & ИП мн. (сред.) & 1 & - \\
\hline & ВП мн. (муж.) & 1 & - \\
\hline & МП мн. & 1 & - \\
\hline & импф. & 1 & - \\
\hline & 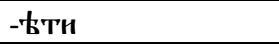 & 46 & 15 \\
\hline & -kN- & 1 & - \\
\hline \multirow[t]{9}{*}{$\mathbf{H}$} & -'ьTн & 32 & 13 \\
\hline & -ьниј- & 12 & 9 \\
\hline & -t女H- & 1 & - \\
\hline & $-\mathrm{kro}$ & 4 & 2 \\
\hline & Р ед. (муж.) & 1 & - \\
\hline & -† (ИП, жен.р.) & 1 & - \\
\hline & ДП мн. (жен.) & 2 & - \\
\hline & прил. ВП мн. & 1 & 9 \\
\hline & нЊжє (мест.) & 1 & - \\
\hline$A$ & импф. & 2 & - \\
\hline \multirow[t]{3}{*}{$\mathbf{T}$} & $\mathrm{B}=\mathrm{P}$ & 1 & - \\
\hline & -t女h- & 3 & - \\
\hline & импф. & 1 & - \\
\hline
\end{tabular}

В первую очередь отметим, что употребление $\mathbf{b}$ в новой для русских рукописей функции оказывается возможным благодаря достаточно последовательному соблюдению рамок его применения: в большинстве позиций, где такой ↔ используется, он 
заметно преобладает над традиционными написаниями, и при этом есть контрастные позиции, в которых, напротив, ['а] передаётся только традиционным способом (они в таблице не представлены).

Данные Таблицы 4 наглядно показывают, что основная масса употреблений $\mathbf{k}$ в значении ['а] относится к местоимениям всњкын (всьчьскын) и весь в форме И-ВП мн.ч. сред.р. (всњ), а также к отдельным группам словоформ после мягких сонорных $\rho, \boldsymbol{\Lambda}, \mathbf{н .}$

Написания после сонорных показывают, что для этой группы написаний ведущим был морфологический критерий. Новая орфограмма после сонорных используется в основном для записи суффиксов и окончаний, но не любых: с разной последовательностью писец упорядочивает своё употребление в субстантивных и глагольных формах.

В субстантивах особенностью, с которой связано употребление $\mathbf{b}=\left[{ }^{\prime} a\right]$, является различение на письме омоформ. Основная часть представленных в Таблице 4 форм падежей представлена единичными примерами, что не позволяет уверенно говорить о последовательности писца в их случае. Однако, в частности, после к и $\rho$ оказываются противопоставлены совпадающие флексии РП в муж. и жен. роде. В муж. роде

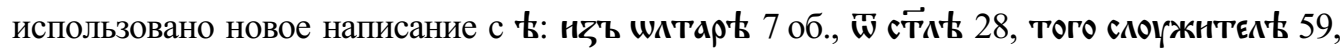

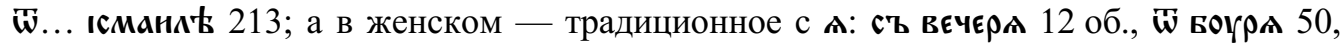

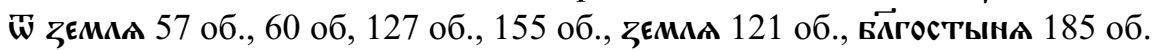

Более явно выражена оппозиция форм ед. и мн. числа - противопоставление омонимичных падежных флексий средствами орфографии в относительно частотных окончаниях РП и В=РП ед. существительных и кратких прилагательных муж. рода (в основном, после к и $)$ ), противопоставленных ВП мн. (и, видимо, ИП мн. в жен. роде). В Р-ВП ед. в 92\% примеров используется новое написание флексии,

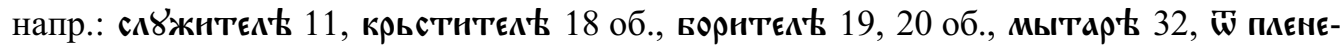

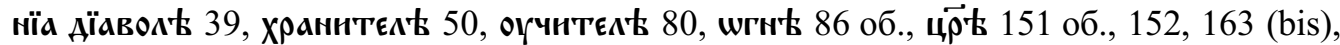

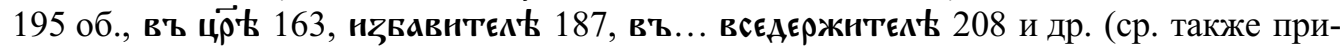
ведённые выше формы РП ед.). В противоположность этим формам в Син. 675 омонимичные флексии И-ВП во множ. числе всего с одним исключением ${ }^{23}$ пишутся в

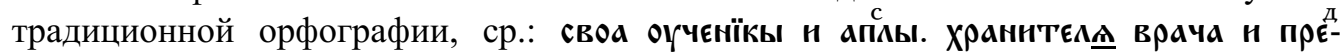

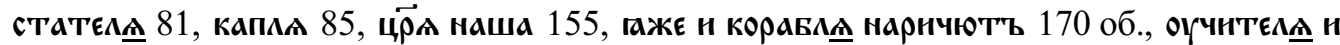
пргїныга 200 об., огчнтекА анөїгганьскыга 205 об. и др.

Представленная дистрибуция — Ł в РП, В=РП ед. муж.р. / ж в РП ед. жен.р., ИВП мн. - очевидным образом коррелирует с разницей в записи этих окончаний в болгарских рукописях: последняя группа флексий содержит этимологический носовой гласный и в южнославянской орфографии записывалась через юс. С опорой на эту особенность болгарского письма писец Син. 675 сохраняет а в РП ед. жен. и в И-ВП мн. Таким образом, традиционный на первый взгляд для древнерусской

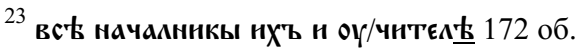


книжной письменности способ обозначения ['а] во флексиях, заимствованный ещё при первом южнославянском влиянии, попав в оппозицию с $\mathbf{b}=[$ ['а], оказывается болгаризмом новой волны - вновь актуализированным последовательным обозначением этимологического носового.

Базовое правило употребления орфограммы $\mathbf{k}=\left[{ }^{\prime} \mathrm{a}\right]$, которое позволяет сформулировать рассмотренный материал существительных, следующее: $\mathbf{k}=\left[{ }^{6} \mathbf{a}\right]$ следует писать в позиции этимологического [a], a A - в позиции этимологического [e]]. Естественно, необходимые «этимологические» сведения брались писцом из орфографии южнославянских рукописей, где оппозиция двух рефлексов сохранялась на письме. Так писец не просто использует букву $\mathbf{b}$ по болгарскому принципу, но и буквально сохраняет дистрибуцию $\mathbf{k} / \mathbf{A}$ - как если бы список Евхология имел среднеболгарский протограф ${ }^{24}$.

Дистрибуция слогов ct / $\mathbf{c} \mathbf{\mathbf { A }}=[\mathrm{s}$ 'а] по всей видимости, имеет ту же основу: употребление съ ограничено теми частотными лексемами (формами всњк-, всъ), которые имеют этимологический [a]; напротив, слог сл употребляется там, где и в южнославянских рукописях пишется юс: в постфиксе -сла, а также, например, в формах типа носАщ-, АєсАть с этимологическим [е]].

После сонорных базовое правило действует, хотя и менее последовательно, в связи с большей дробностью возможных позиций, в составе глагольных форм. Писец последовательно оставляет традиционный А в окончаниях 3 л. мн.ч. (типа сквернать 46 об., творать 182 об., въводАть 195 об.), а новую орфограмму использует в глаголах III класса на -гатн. Однако, как показывают данные Таблицы 4, применяя $\mathbf{k}=[$ 'a] в глаголах, писец допускает заметно больше отклонений в пользу A, чем в субстантивах (27\%). При этом отклонения допускаются только в 9\% форм инфинитива (3 из 11) и чаще - в 28\% примеров (31 форма из 117) - в формах настоящего времени и причастиях (типа нбБавлАга, въдварАютьсА, оукрҺпкАюцїн, прекланакть, покланаюма). Вероятно, в этих формах без опоры на антиграф было сложнее выдерживать применение $\mathbf{k}=[$ [a] под влиянием грамматически однородных форм с этимологическим юсом типа творАть, мокАцнхъ, ХранАн и т. П. (ср. отличие в инфинитиве: творнти / претварьтн).

Вся совокупность примеров использования ‘ в значении ['а] в Син. 675 показывает, что применительно к данной орфографической системе правильнее говорить не просто о заимствовании южнославянской орфограммы, но о заимствовании орфограммы вместе со всеми позициями, в которых она используется в источнике заимствования. Следствием этого является изменение статуса графемы А в системе: её употребление оказывается ориентированным на юсовую орфографию южнославянских памятников, и поэтому тоже оказывается болгаризированным.

\footnotetext{
${ }^{24}$ Ср. в частности примеры М. Г. Гальченко из «Бесед Григория Двоеслова» 1444 г., списанных с болгарского оригинала, где $\mathbf{b}=[$ ['a] ожидаемо присутствует только на месте этимологического [а] [Гальченко 2001: 208].
} 


\section{3. Формулировка основного принципа}

В орфографии основного писца Син. 675 представлено большое количество южнославянизмов. Основная их часть принадлежит к выделенному М. Г. Гальченко минимальному списку признаков, усваивавшихся русской письменностью на рубеже XIV-XV вв. раньше остальных. К наиболее ярким особенностям орфографии, выделяющим Син. 675 на фоне рукописей данного периода, следует отнести частое (при обычно слабой представленности) применение or $=[\mathrm{ju}]$, а также последовательное (при редкости подобных систем на рубеже XIV-XV вв.) использование $\mathbf{b}=[$ 'a], особенно примечательное при отсутствии у рассматриваемого перевода Евхология Великой церкви среднеболгарского антиграфа. Необычно ранним нужно признать и наличие в рукописи полного набора диакритических знаков.

По всей видимости, формирование описанного выше круга написаний связано с целенаправленной кодификаторской деятельностью, в ходе которой был проведен отбор на основании продуманных критериев. Внешне разнородный набор орфографических черт (относящихся к минимальному, расширенному и максимальному спискам) отобран по единому принципу: писец Син. 675 использует только те новые южнославянские орфограммы, которые не требовали введения в систему написаний новых графем или аллографов. В соответствии с этим принципом пи-

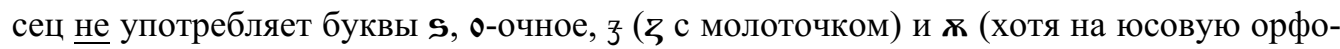
графию, как показано в 2.2.3, несомненно ориентируется).

Отступления от общего принципа наблюдаются в орфографии Син. 675 в тех случаях, когда последовательное его соблюдение привело бы к внутренним противоречиям системы. Например, написания через \& рефлексов *tert появляются редко, поскольку активно эта буква применяется в новом значении ['a]; в единичных случаях писец использует по среднеболгарскому стандарту ь после конечного твёрдого [t], т. к. в системе используются болгаризмы (типа єстт), где, напротив, ъ соответствует конечному мягкому [ $\left.\mathrm{t}^{\prime}\right]$. Написания с редуцированными являются наименее чёткими в системе Син. 675, возможно поэтому писец - уже при наличии двух других южнославянизмов на материале $\mathbf{z}, \mathbf{b}-$ не решился вводить ещё и орфограмму tръt для передачи *tъrt. Подобные исключения лишний раз показывают детальную разработанность и продуманность орфографии Син. 675.

При объяснимых отступлениях писец в целом достаточно полно реализовал принцип использовать южнославянизмы в пределах традиционного набора графем: последовательно используется даже признак из максимального набора. Лексически ограниченные орфограммы, вписывающиеся в этот принцип, также используются в Син. 675 (в частности, грецизированное написание слов с корнем агтєл- -82 об., $87,102,103,106$ и др.). Это создало специфическую орфографическую систему, наличие которой в переводе Евхология Великой церкви позволяет связать её разработку непосредственно с митрополитом Киприаном и его переводческим кружком. 


\section{4. Реализация орфографического принципа в других рукописях конца XIV в.}

Из рукописей рубежа XIV-XV вв., изученных М. Г. Гальченко, наибольшей близостью по составу признаков к Син. 675 (в первую очередь, использованием $\mathbf{t}=$ ['a $]$ при отсутствии $\boldsymbol{x}-$ см. [Саенко 1984: 189]) характеризуется список Лествицы 1402 г. («Тверской», «Тимофеевской»), антиграф которой был сделан «с митрополича списка» [Гальченко 2001: 428]. Показательно также наличие таких значимых, на наш взгляд, признаков, как $\mathbf{t}=[$ 'a] и постоянное or $=[\mathrm{ju}]$ в переписанной Киприаном Лествице 1387 г. [Князевская, Чешко 1980: 285] ${ }^{25}$.

Описанная система орфографических правил реализует принцип подражания болгарскому письму в пределах заданного инвентаря графем с максимальной полнотой, в связи с чем её можно определить как декоративную. Цель использования такого набора приёмов, по-видимому, состояла в том, чтобы визуально подчеркнуть реформаторский характер деятельности Киприановского кружка. Однако наряду с развёрнутой системой, представленной в списке Евхология Великой церкви, мог быть использован и её сокращённый вариант.

Об этом позволяет судить письмо так называемого Исидорова служебника (Vat. slav. 14), рукописи конца XIV в., которая, по мнению Т. И. Афанасьевой, была связана с тем же кругом книжников, что и список Евхология, и вместе с Син. 675 входила в единый комплект книг для богослужения в кафедральных соборах Москвы [Афанасьева 2017]. Орфография этой рукописи содержит признаки, обусловленные влиянием южнославянской письменности; их меньше, чем в Син. 675 , но все они входят в число описанных выше для предполагаемой системы, связанной с митрополитом Киприаном. Сам по себе этот факт не мог бы однозначно говорить в пользу единого книгописного центра происхождения орфографических систем Vat. slav. 14 и Син. 675, но ряд частных совпадений в написаниях двух рукописей делает правдоподобным предположение о наличии полного и сокращённого варианта орфографических приёмов в практике одного и того же круга книжников.

Так же, как и в Син. 675, в Исидоровом служебнике используются графемы ы и or, и даже более последовательно: например, графема ы использована в рукописи всего 19 раз. Как и в рукописи Евхология, в Служебнике применяются маркированные знаки препинания - запятая и большая красная точка (появляется с л. 83, в тексте Литургии Преждеосвящённых даров). Набор надстрочных знаков в Vat. slav. 14 был описан в работе О. Горбача: показательно, что отсутствует только великий апостроф, редкий и в Син. 675 [Горбач 1966: 14]. Из значимых частных совпадений двух рукописей следует отметить использование оксии в Vat. slav. 14 в неакцентной функции, вместо знака придыхания над буквой а: съгласїа́, втораá [Там же: 20] (ср. подобные написания в Син. 675 в 2.2.1.2), такие написания О. Горбач относит к

${ }^{25}$ Наличие в этой рукописи графемы ж и отражение мены юсов [Князевская, Чешко 1980: 286] может быть связано с тем, что, в отличие от Евхология Великой церкви, она имела болгарский протограф. 
«гіперистичним». Кроме того, подобно писцу Евхология, писец Служебника отме-

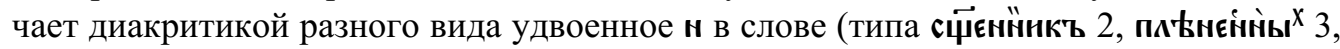

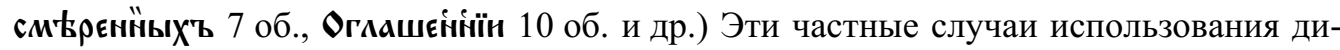
акритики реализуют актуальный для киприановской орфографии принцип совмещения двух приёмов.

В использовании буквенных орфограмм Исидоров служебник близок к рукописи Евхология Великой церкви в рамках минимального набора признаков. Писцы Служебника пользуются орфограммами $\mathbf{a}=[\mathrm{ja}]$ и or $=[\mathrm{ju}]$, хотя второй - в заметно меньшей степени. B Vat. slav. 14 наиболее последовательно $\mathbf{a}=$ [ja] пишется после ї (в 95\% возможных позиций при 98\% в Син. 675); близка по частотности и орфограмма аa (41\% при $45 \%$ в Син. 675); орфограмма ња применяется даже последовательнее, чем в рукописи Евхология (86\% против 48\%); используется $\mathbf{a}=[\mathrm{ja}]$ и в позиции после букв других гласных (н, $\mathbf{b}, \mathbf{b}, \mathbf{t}, \mathbf{o} / \mathbf{w}, \mathbf{⿰} / \mathbf{o r})$ ), но в два-три раза реже, чем в Син. 675. Важной деталью является пример плеонастического написания на основе этой орфограммы: Жертва вечернАаa 86 (ср. прєпогаасавсА в СИн. 675). Орфограмма or $=[\mathrm{ju}]$ во всех позициях уступает показателям Син. 675, но чаще всего также применяется после ї (в 17\% позиций при 64\% в Син. 675).

Почти совпадает по частотности применения в двух рукописях ї перед буквами гласных (57\% в Vat. slav. 14 против 56\% в Син. 675).

При обозначении рефлексов *dj в Исидоровом Служебнике представлена конкуренция русского и болгарского написаний, но, в отличие от Син. 675 , с перевесом в пользу русского $(61 \%, 51$ пример из 83, против $32,5 \%$ в Син. 675). При этом показательно совпадение в обеих рукописях частных правил распределения вариантов (см. в 2.2.1.6). B Vat. slav. 14 также без исключений новое написание (жА) используется на конце слов: 12 раз в императиве даждъ/Ааждь, один раз в императиве внждъ 54 об. и один раз в форме $\boldsymbol{w}_{\text {Ає }} \boldsymbol{*}^{\mathrm{A}} \mathbf{b} 148$ об. Последняя форма показывает, что правило относится не только к императивным формам (ср.: три раза слово одєжа, стоящее в других падежных формах, пишется в Vat. slav. 14 через ж). Как и в Син. 675, писцы ватиканской рукописи пишут слово ноүжа во всех примерах (9 раз) с русским рефлексом.

Актуально для переписчиков Служебника написание двойного н в причастиях. Как и в рукописи Евхология Великой церкви, в Служебнике это написание может выходить за рамки причастных форм и использоваться в прилагательных (нєдосто-

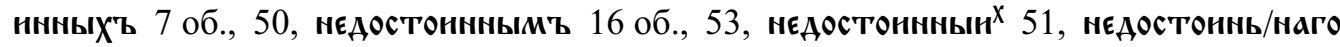

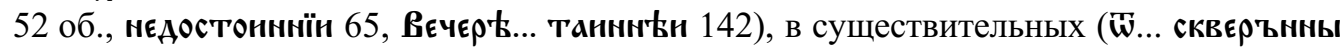
75 об.) и в наречиях (таннно 101 об., вєзБольънънно 105).

Наконец, из признаков минимального набора, рассмотренных для списка Евхология (2.2.1.8), в Vat. slav. 14 один раз встретилось и гиперкорректное оформление приставки на -z: ннцспоскн 54 об.

Признаки расширенного и максимального наборов переписчикам Служебника не свойственны, с некоторыми важными оговорками. Во-первых, отсутствие некоторых признаков наблюдалось и в Син. 675. В обеих рукописях оказывается похожим 
по традиционности оформление рефлексов *tert и *tъrt: преобладающим является русский вариант написания, однако в единичных случаях появляются и болгаризмы. Слог pt в *tert появляется в Vat. slav. 14 несколько раз в приставке прt-, в основном на лл. 89-93 (Пръмогарость 51, Прқстоую 89 об., 91 об., 93, Пръстүюю 92 об., пртклоннвъ 143) и один раз в другой морфеме (прострьвша 140). Как и в Син. 675, в Служебнике единичны болгарские написания *tъrt [Горбач 1966: 16]. Во-вторых, при отсутствии в Vat. slav. 14 группы болгаризированных написаний, активной в Син. 675 , соответствующие написания в рукописи всё же фиксируются. Так, мена конечного ъ на ь в Служебнике встретилась дважды, один из примеров - с прав-

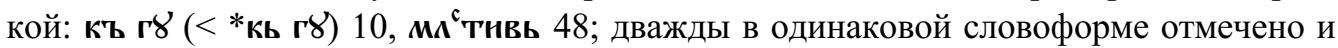

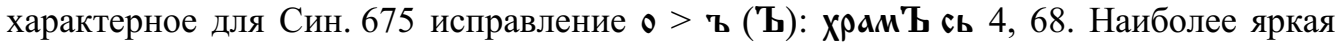
особенность киприановской орфографической системы - $\mathbf{k}=\left[{ }^{\prime} \mathrm{a}\right]-$ также в еди-

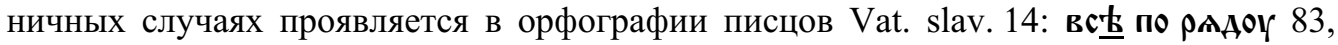
всАкоГО врага и Борнтек妄 89. Оба примера встретились в тексте литургии Преждеосвященных Даров, которая представлена в Vat. slav. 14 в редакции митрополита Киприана [Афанасьева 2004: 118], а следовательно ł в его болгарском значении не мог проникнуть из болгарского антиграфа и, так же как и в Син. 675, входил в компетенцию древнерусского книжника.

Из совпадений Vat. slav. 14 с Син. 675 можно упомянуть также грецизированное оформление основы аггєк- [Горбач 1966: 13].

Итак, сопоставление орфографических приёмов Исидорова служебника и списка Евхология показывает, что участвовавшие в их написании книжники владели одинаковым набором графико-орфографических навыков; помимо самого набора для некоторых приёмов совпадают также частные правила их реализации, касающиеся дистрибуции дублетных написаний (ср. распределение ж/жА). В рукописи Евхология Великой церкви этот набор правил и навыков реализован полностью, а писцам, работавшим над переписыванием Служебника, судя по единичным примерам, он был знаком, но, по всей видимости, их целью было переписать текст, не применяя самые непривычные для древнерусского узуса орфограммы (or $=[\mathrm{ju}]$ и $\mathbf{~}=\left[{ }^{\prime} \mathrm{a}\right]$ ).

\section{Литература}

Афанасьева $2004-$ Т. И. Афанасьева. Славянская литургия Преждеосвященных Даров XII-XV вв.: текстология и язык. СПб., 2004.

Афанасьева $2014-$ - Т. И. Афанасьева. К вопросу о времени и месте славянского перевода Евхология Великой церкви // Русский язык в научном освещении. № 1 (27), 2014. C.237-251.

Афанасьева 2015 - Т. И. Афанасьева. Славянская версия Евхология Великой церкви и ее греческий оригинал // Лингвистическое источниковедение и история русского языка. 2014-2015. М., 2015. С. 9-43. 
Афанасьева 2017 - Т. И. Афанасьева. Рукопись Vat. slav. 14 как служебник митрополита Киприана [тезисы доклада] // Древняя Русь. Вопросы медиевистики. № 3, 2017. С. $11-12$.

Ван-Вейк 1957 - Н. Ван-Вейк. История старославянского языка. М., 1957.

Гальченко 2001 - М. Г. Гальченко. Книжная культура. Книгописание. Надписи на иконах Древней Руси. Избранные работы /Труды Центрального музея древнерусской культуры и искусства имени Андрея Рублева, I/. М., 2001.

Горбач 1966 - О. Горбач. Три церковнослов'янські літургічні рукописні тексти Ватиканської бібліотеки / Видання Українського католицького університету ім. Св. Климентія папи. Праці Філософічно-Гуманістичного Факультету. Том I. Рим, 1966.

Горский, Невоструев $1869-$ А. В. Горский, К. И. Невоструев. Описание славянских рукописей Московской Синодальной библиотеки. Отд. III: Книги богослужебные. Ч. 1. М., 1869. С. 128-153.

Живов 2006 - В. М. Живов. Въ пльну у ангеловъ, на дикомъ брегъ — ахъ! // Живов В. М. Восточнославянское правописание XI-XIII века. М., 2006. С. 178-199.

Загребин $2006-$ В. М. Загребин. Исследование памятников южнославянской и древнерусской культуры. М.-СПб., 2006.

Князевская, Чешко $1980-O$. А. Князевская, E. В. Чешко. Рукописи митрополита Киприана и отражение в них орфографической реформы Евфимия Тырновского // Ученици и последователи на Евтимий Тьрновски. Втори международен симпозиум, Велико Тьрново, 20-23 май 1976. София, 1980. С. 282-292.

Кузьмина, Немченко 1982 - И. Б. Кузьлина, Е. В. Немченко. История причастий // Историческая грамматика русского языка. Морфология. Глагол. М., 1982. С. $280-411$.

Мольков 2016 - Г. А. Мольков. Особенности языка и письма Погодинского евангелия (РНБ Погод. 11) // Die Welt der Slaven. 2016. Jg. 61, Heft 2. С. 230-253.

Обнорский $1912-$ С. П. Обнорский. К истории глухих в Чудовской псалтыри ХІ века // Русский филологический вестник. Т. 68, № 4. 1912. С. 337-379.

Осипов 2010 - Б. И. Осипов. Судьбы русского письма. Омск, 2010.

Саенко 1984 - Л. П. Саенко. Палеография, графика и орфография Тверской Лествицы 1402 года: Дисс. ... канд. филол. наук. М., 1984.

Соболевский $1907-$ А. И. Соболевский. Лекции по истории русского языка. 4-е изд. М., 1907.

Турилов 2012 - А. А. Турилов. «Второе южнославянское влияние» и русская культура XIV-XV вв. // Турилов А. А. Межславянские культурные связи эпохи Средневековья и источниковедение истории и культуры славян: Этюды и характеристики. М., 2012. С. 519-555.

Успенский 2002 - Б. А. Успенский. История русского литературного языка. М., 2002.

Щепкин 1899 - В. Н. Щепкин. Рассуждение о языке Саввиной книги. СПб., 1899. 


\section{Georgiy A. Mol'kov}

Institute for Linguistic Studies, RAS

(Russia, St. Petersburg)

georgiymolkov@gmail.com

\section{ORTHOGRAPHIC PRINCIPLES OF CYPRIAN'S CIRCLE (ACCORDING TO THE MOSCOW MS. SHM, SYNODAL 675)}

The article presents an analysis of the orthographic rules used by the scribe of the codex Sin. 675 which contains the Slavic version of the Euchologion of the Great Church translated in the circle of Metropolitan Cyprian. A significant number of analysed orthographic features were borrowed from Bulgarian literary tradition. These orthograms were adopted by Russian scribes in accordance with a general principle and constitute a spelling system specific to the turn of the $14^{\text {th }}-15^{\text {th }}$ century manuscripts which were not rewritten from Middle Bulgarian sources. Perhaps this orthographic system was worked out by Cyprian himself specifically for the new translations made in Rus'.

Keywords: Second South Slavic influence; translations of Metropolitan Cyprian; Euchologion of the Great Church; orthographic standard

\section{References}

Afanas'yeva T. I. Slavyanskaya liturgiya Prezhdeosvyashchennykh Darov XII-XV vv.: tekstologiya i yazyk. St. Petersburg, 2004.

Afanas'yeva T. I. K voprosu o vremeni i meste slavyanskogo perevoda Evkhologiya Velikoi tserkvi. Russkii yazyk v nauchnom osveshchenii. № 1 (27), 2014, pp. 237-251. (In Russ.)

Afanas'yeva T. I. Slavyanskaya versiya Evkhologiya Velikoy tserkvi i ee grecheskiy original. Lingvisticheskoe istochnikovedenie i istoriya russkogo yazyka. 2014-2015. Moscow, 2015, pp. 9-43.

Afanas'yeva T. I. Rukopis' Vat. slav. 14 kak sluzhebnik mitropolita Kipriana [tezisy doklada]. Drevnyaya Rus'. Voprosy medievistiki. № 3, 2017, pp. 11-12. (In Russ.)

Gal'chenko M. G. Knizhnaya kul'tura. Knigopisanie. Nadpisi na ikonakh Drevney Rusi. Izbrannye raboty [Trudy Tsentral'nogo muzeya drevnerusskoi kul'tury i iskusstva imeni Andreya Rubleva, I]. Moscow, 2001.

Gorbach O. Tri tserkovnoslov'yans'ki liturgichni rukopisni teksti Vatikans'koï biblioteki [Vidannya Ukraïns'kogo katolits'kogo universitetu im. Sv. Klimentiya papi. Pratsi Filosofichno-Gumanistichnogo Fakul'tetu. Vol. I]. Rome, 1966.

Gorskiy A. V., Nevostruev K. I. Opisanie slavyanskikh rukopisei Moskovskoi Sinodal'noi biblioteki. Vol. 3: Knigi bogosluzhebnye. Part 1. Moscow, 1869, pp. 128-153. 
Knyazevskaya O. A., Cheshko E. V. Rukopisi mitropolita Kipriana i otrazhenie v nikh orfograficheskoy reformy Evfimiya Tyrnovskogo. Uchenitsi i posledovateli na Evtimiy T"rnovski. Vtori mezhdunaroden simpozium, Veliko T"rnovo, 20-23 may 1976. Sofiya, 1980, pp. 282-292.

Kuz'mina I. B., Nemchenko E. V. Istoriya prichastii. Istoricheskaya grammatika russkogo yazyka. Morfologiya. Glagol. Moscow, 1982, pp. 280-411.

Mol'kov G. A. Osobennosti yazyka i pis'ma Pogodinskogo evangeliya (RNB Pogod. 11). Die Welt der Slaven. 2016, Jg. 61, Heft 2, S. 230-253. (In Russ.)

Obnorskiy S. P. K istorii glukhikh v Chudovskoi psaltyri XI veka. Russkiy filologicheskiy vestnik. Vol. 68, No. 4. 1912, pp. 337-379. (In Russ.)

Osipov B. I. Sud'by russkogo pis'ma. Omsk, 2010.

Saenko L. P. Paleografiya, grafika i orfografiya Tverskoy Lestvitsy 1402 goda: Diss. ... PhD. Moscow, 1984.

Shchepkin V. N. Rassuzhdenie o yazyke Savvinoi knigi. St. Petersburg, 1899.

Sobolevskiy A. I. Lektsii po istorii russkogo yazyka. 4th ed. Moscow, 1907.

Turilov A. A. «Vtoroe yuzhnoslavyanskoe vliyanie» i russkaya kul'tura XIV-XV vv. In: Turilov A. A. Mezhslavyanskie kul'turnye svyazi epokhi Srednevekov'ya i istochnikovedenie istorii i kul'tury slavyan: Etyudy i kharakteristiki. Moscow, 2012, pp. 519-555.

Uspenskiy B. A. Istoriya russkogo literaturnogo yazyka. Moscow, 2002.

Van-Veyk N. Istoriya staroslavyanskogo yazyka. Moscow, 1957.

Zagrebin V. M. Issledovanie pamyatnikov yuzhnoslavyanskoi i drevnerusskoi kul'tury. Moscow-St. Petersburg, 2006.

Zhivov V. M. V plъnu u angelov, na dikom' bregb — akh', In: Zhivov V. M. Vostochnoslavyanskoe pravopisanie XI-XIII veka. Moscow, 2006, p. 178-199. 